E. T. Jones; Past Presidents, N. E. Rowe, Sir Sydney Camm and Sir William Farren; President-elect, G. R. Edwards ; Vice-Presidents, Sir Arnold Hall, P. G. Masefield and Dr. E. S. Moult; Honorary Treasurer, Major G. P. Bulman; and Secretary, A. M. Ballantyne.

\section{Rutherford Memorial Lecture and Scholarship}

UNDER the terms of the scheme to commemorate the late Lord Rutherford of Nelson, the Council of the Royal Society has appointed Prof. E. N. da C. Andrade to deliver the Rutherford Memorial Lecture for 1957 in Australia.

The Council of the Royal Society has also appointed Mr. A. M. Segar, a graduate of the University of Melbourne, as a Rutherford Scholar for three years from October 1 , to carry out studies in nuclear physics at the University of Birmingham.

\section{Human Problems of Industrial Communities within the British Commonwealth}

A study conference on "The Human Problems of Industrial Communities within the Commonwealth and Empire", under the presidency of H.R.H. the Duke of Edinburgh, and with Sir Harold Hartley as chairman, will be held in. Oxford during July 9-27. The purpose of the conference is to conduct a practical study of the human aspects of industrialization, and in particular those factors which make for satisfaction, efficiency and understanding, both inside industrial organizations and in the everyday relations between industry and the community around it. It will not deal, however, with those matters which oome within the normal scope of industrial negotiation. As the conference is independent in character, no government or organization is represented officially, and the members have all been invited as individuals and not delegates. About 280 men and women will be attending, mainly 25-45 years old, and all of them responsible persons engaged in the manager/employer or trade union/operative roles of industry (including industrially organized agriculture and governmentowned undertakings). The approximate distribution of membership is : Great Britain, 90 ; Canada, 30 ; Australia, 25 ; India, 25 ; Union of South Africa, 18 ; Malaya and the Far East, 14; Caribbean area, 13 ; Federation of Rhodesia and Nyasaland, 12 ; Pakistan, 12 ; West Africa, 11 ; New Zealand, 10 ; East Africa, 7 ; Oceanic areas, 7 ; and Ceylon, 6. The conference will be divided into twenty study groups of fourteen members each, and after the introductory sessions they will set off for nine days on independent tours of industrial centres in Britain. The last five days of the conference will be spent in Oxford, when the final reports of each group will be discussed. Further information can be obtained from the conference secretary, Peter Parker, 48 Bryanston Square, London, W.1.

\section{Announcements}

The Warner Memorial Medal of the Textile Institute has been awarded to Dr. J. M. Preston, research manager of British Enka, Ltd., of Aintree. The Medal was inaugurated in 1930, in memory of the late Sir Frank Warner, a past president and chairman of Council of the Institute, and is awarded for outstanding work in textile science and technology, the results of which have been published, and particularly for work published in the Journal of the Textile Institute.
The Salters' Company has elected the following to be Salters' Fellows for the year 1956-57: F. W. Eastwood and R. C. Sheppard (Department of Organic Chemistry, Cambridge); Dr. L. Keay (Queen Mary College, London); and Dr. M. J. Stephen (continuation of fellowship for 1955-56 ; Department of Mathematics, Oxford). Salters' scholarships have been awarded to the following : A. R. Sanderson (King's College, Newcastle upon Tyne) ; P. S. Houston (Battersea Polytechnic, London); A. A. Webb and P. L. Levine (Imperial College of Science and Technology, London); and B. B. Hunt (University of Cambridge).

SIR K. S. KRISHNAN, director of the National Physical Laboratory of India, Now Delhi, will give a lecture at the Royal Society on June 28 at 4.30 p.m. in which he will give a short account of the scientific and technical work done in the various divisions of the Laboratory. The lecture is open to the public, who should write beforehand, however, to the Assistant Secretary, Royal Society, Burlington House, London, W.1, notifying their intention to be present.

THE Manchester Joint Research Council is holding a meeting on "Automation" in the University of Manchester on July 9 . The meeting will be addressed by the Earl of Halsbury. Further information can be obtained from the Council, c/o Manchester Chamber of Cornmerce, Ship Canal House, King Street, Manchester 2.

THE Nutrition Society is holding a symposium on "Grassland and the Feeding of Livestock" in the University of Reading on July 20, under the chairmanship of Prof. H. D. Kay. Further information can be obtained from the honorary programmes secretary of the Society, Dr. R. J. L. Allen, c/o Beecham Foods, Ltd., Brentford, Middlesex.

The Plant Breeders' Conference organized by the Agricultural Research Council will be held this year in the Plant Breeding Institute, Cambridge, during July 4-5. About a hundred representatives are expected to attend, including the staffs of plant breeding institutes, other plant breeders and geneticists from university departments.

A symposium on "Chemisorption", organized by the Chemical Society, will be held in the University College of North Staffordshire, Keele, during July 16-19. After an opening session on the theory of chemisorption, there will be four sessions dealing with chemisorption on insulators, metals, carbon and semiconductors, respectively. The fee for the symposium is 2 guineas (10s. for Fellows of the Society). Registration forms, to be returned by July 1, and further information can be obtained from the General Secretary, Chemical Society, Burlington House, London, W.I.

THE Non-Destructive Testing Group of the Institute of Physics will hold its summer meeting during July 11-14 in the H. H. Wills Physical Laboratory, University of Bristol, when the subject, will be "Physics of Some New Aspects of NonDestructive Testing". The proceedings will be published later as a supplement of the British Journal of Applied Physics. The conference will be open to non-members of the Group. Enrolment forms, to be returned by June 25, can be obtained from the Deputy Secretary, Institute of Physics, 47 Belgrave Square, London, S.W.1. 